7. Engel AG, Rebouche CJ, Wilson DM, Glasgow AM, Romshe CA, Cruse RP 1981 Primary systemic carnitine deficiency. II. Renal handling of carnitine. Neurology 31:819-825

8. Coates PM, Hale DE, Stanley CA, Glasgow AM 1984 Systemic carnitine deficiency simulating Reye syndrome. J Pediatr 105:679

9. Coates PM, Cortner JA, Hoffman GM, Brown SA 1979 Acid lipase activity of human lymphocytes. Biochim Biophys Acta 572:225-234

10. Frerman FE, Sabran JL, Taylor JL, Grossberg SE 1983 Leucine catabolism during the differentiation of 3T3-L1 cells. Expression of a mitochondrial enzyme system. J Biol Chem 258:7087-7093

11. Frerman FE, Goodman SI 1985 Fluorometric assay of acyl-CoA dehydrogenases in normal and mutant human fibroblasts. Biochem Med 33:38-44

12. Husain M, Steenkamp DJ 1983 Electron transfer flavoprotein from pig liver mitochondria. A simple purification and re-evaluation of some of the molecular properties. Biochem J 209:541-545

13. McKean MC, Beckmann JD, Frerman FE 1983 Subunit structure of electron transfer flavoprotein. J Biol Chem 258:1866-1870

14. Lowry OH, Rosebrough NJ, Farr AL, Randall RG 1951 Protein measurement with the Folin phenol reagent. J Biol Chem 193:265-275

15 Roe CR, Millington DS, Maltby DA, Bohan TP, Kahler SG, Chalmers RA 1985 Diagnostic and therapeutic implications of medium chain acylcarnitines in the medium chain acyl-CoA dehydrogenase deficiency. Pediatr Res (in press)

16. Howat AJ, Bennett MF, Vareind S, Shaw L 1984 Deficiency of medium-chain acylcoenzyme A dehydrogenase presenting as the sudden infant death syndrome. Br Med J 288:976

17. Lindstedt S, Norberg K, Steen G, Wahl E 1976 Structure of some aliphatic dicarboxylic acids found in the urine of an infant with congenital lactic acidosis. Clin Chem 22:1330-1338

18. Chalmers RA, Lawson AM, Whitelaw A, Purkiss P 1980 Twin siblings with a Reye's-like syndrome associated with an abnormal organic aciduria, hypoglycemia, diarrhea, and vomiting with close similarities to Jamaican vomiting sickness. Pediatr Res 14:1097-1103

19. Del Valle JA, Garcia MJ, Merinero B, Pérez-Cerdá C, Roman F, Jimenez A Ugarte M, Martinez-Pardo M, Camarero C, Del Olmo R, Duran M, Wadman SK 1984 A new patient with dicarboxylic aciduria suggestive of me- dium-chain acyl-CoA dehydrogenase deficiency presenting as Reye's syndrome. J Inher Metab Dis 7:62-64

20. Truscott EJW, Hick L, Pullin C, Halpern B, Wilcken B, Griffith $H$, Silink M, Kilham H, Grunseit F 1979 Dicarboxylic aciduria: the response to fasting. Clin Chim Acta 94:31-39

21. Naylor EW, Mosovich LL, Guthrie R, Evans JE, Tieckelmann H 1980 Intermittent non-ketotic dicarboxylic aciduria in two siblings with hypoglycemia: an apparent defect of $\beta$-oxidation of fatty acids. $J$ Inher Metab Dis 3:19-24

22. Hale DE, Batshaw ML, Coates PM, Frerman FE, Goodman SI, Singh I, Stanley CA 1985 Long-chain acyl coenzyme A dehydrogenase deficiency: an inherited cause of nonketotic hypoglycemia. Pediatr Res 19:666-670

23. Rhead WJ, Tanaka K 1980 Demonstration of a specific mitochondrial isovaleryl-CoA dehydrogenase deficiency in fibroblasts from patients with isovaleric acidemia. Proc Natl Acad Sci USA 77:580-583

24. Amendt BA, Rhead WJ 1984 A simple assay for medium chain acyl-CoA dehydrogenase (MCADH) activity in dicarboxylic aciduria (DCA) fibroblasts. Pediatr Res 18:290A(abstr)

25. Ikeda Y, Dabrowski C, Tanaka K 1983 Separation and properties of five distinct acyl-CoA dehydrogenases from rat liver. Identification of a new 2methyl branched chain acyl-CoA dehydrogenase. J Biol Chem 258:10661076

26. Saudubray J-M, Coudé F-X, Demaugre F, Johnson C, Gibson KM, Nyhan WL 1982 Oxidation of fatty acids in cultured fibroblasts: a model system for the detection and study of defects in oxidation. Pediatr Res 16:877-881

27. Colle E, Mamer OA, Montgomery JA, Miller JD 1983 Episodic hypoglycemia with $\psi$-hydroxy fatty acid excretion. Pediatr Res 17:171-176

28. Gregersen N, Lauritzen R, Rasmussen K 1976 Suberylglycine excretion in the urine from a patient with dicarboxylic aciduria. Clin Chim Acta 70:417-425

29. Gregersen N, Rosleff F, Kølvraa S, Hobolth N, Rasmussen K, Lauritzen R 1980 Non-ketotic $\mathrm{C}_{6}-\mathrm{C}_{10}$-dicarboxylic aciduria:biochemical investigations of two cases. Clin Chim Acta 102:179-189

30. Gregersen N, K $\phi$ lvraa S, Rasmussen K, Mortensen PB, Divry P, David M Hobolth N 1983 General (medium-chain) acyl-CoA dehydrogenase deficiency (non-ketotic dicarboxylic aciduria): quantitative urinary excretion pattern of 23 biologically significant organic acids in three cases. Clin Chim Acta 132:181-191

\title{
Aldosterone Metabolism and Transepithelial Potential Difference in Normal and Cystic Fibrosis Subjects
}

\author{
M. R. KNOWLES, J. T. GATZY, AND R. C. BOUCHER \\ Departments of Medicine and Pharmacology, University of North Carolina at Chapel Hill,
} Chapel Hill, North Carolina 27514

\begin{abstract}
The transepithelial potential difference (PD) is raised across cystic fibrosis (CF) respiratory epithelia. This raised voltage reflects active sodium absorption across a relatively chloride impermeable membrane. Because relatively little is known about the regulation of the rate of sodium absorption across mammalian airways, we assessed the possible contribution of aldosterone to the PD in normal and CF respiratory epithelia. Aldosterone excretion in
\end{abstract}

Received December 14, 1983; accepted February 27, 1985.

Correspondence to M. R. Knowles, M.D., University of North Carolina, Department of Pulmonary Medicine, 724 Burnett-Womack Building $229 \mathrm{H}$, Chapel Hill, NC 27514.

Presented in part at the 23rd Annual Cystic Fibrosis Club Meeting, Washington, D.C., May 1982. Supported by NIH Grants HL00787, HL16674, and HL22924; Cystic Fibrosis Foundation RRDP Grant R002 4-01; and Clinical Research Unit Grant RR00040. R.C.B. is an established investigator of the American Heart Association. five CF patients was $12.2 \pm 0.9 \mu \mathrm{g} / 24 \mathrm{~h}$, a mean value not different from normal control subjects $(13.6 \pm 1.5 \mu \mathrm{g} / 24$ $\mathrm{h}, \boldsymbol{n}=5$ ). Despite similar aldosterone excretion rates, nasal PD was more than 2-fold greater in the CF patients $(-53.6$ $\pm 6.4 \mathrm{mV})$ than normal subjects $(-21.3 \pm 1.4 \mathrm{mV})$. The effect of an aldosterone antagonist, spironolactone, on aldosterone excretion and nasal and rectal $P D$ was evaluated in four CF patients and five normal subjects. During spironolactone administration, aldosterone excretion increased (2- to 4-fold) and rectal PD decreased in both groups. However, nasal PD was unchanged in each group (CF $=-52.1 \pm 4.3 \mathrm{mV}$ pre, $-53.6 \pm 1.4 \mathrm{mV}$ during; normal $=-21.2 \pm 3.1 \mathrm{mV}$ pre, $-21.6 \pm 3.2 \mathrm{mV}$ during). We conclude that neither increased aldosterone secretion rates nor organ sensitivity to aldosterone can account for the abnormally raised PD that characterizes the respira- 
tory epithelium of subjects with CF. (Pediatr Res 19: 676679, 1985)

Abbreviat
CF, cystic fibrosis
PD, potential difference
CRU, Clinical Research Unit
BUN, blood urea nitrogen

$\mathrm{CF}$ is characterized by thick and tenacious secretions which tend to obstruct exocrine ducts and epithelial-lined organ passages (1). Because systematic assessment of the mucin component of respiratory "secretions" in CF patients has failed to identify a unique abnormality in the mucus glycoproteins (2), and because the secretions of the gut, reproductive tract, and airways of CF patients appear to have a reduced water content (3), we have recently explored abnormalities in the epithelial ion transport processes that regulates the salt and water content of respiratory secretions of CF patients.

The transepithelial electric $\mathrm{PD}$, a parameter that reflects active ion transport and passive ion permeability, is raised across the nasal and lower airway epithelium of CF patients as compared to healthy and disease control subjects (4). Recent in vitro studies have suggested that the rate of active $\mathrm{Na}^{+}$absorption across $\mathrm{CF}$ respiratory epithelia is raised (5) and that the $\mathrm{Cl}^{-}$permeability of $\mathrm{CF}$ respiratory epithelium is reduced by $\sim 50 \%$ compared to tissue from normal subjects (6). Other studies have demonstrated a reduction of PD with amiloride, a selective inhibitor of $\mathrm{Na}^{+}$ transport, and support the notion that $\mathrm{Na}^{+}$is actively absorbed across $\mathrm{CF}$ airway surfaces in vivo (7). Thus it appears that active $\mathrm{Na}^{+}$absorption persists at a significant rate across CF airways in vivo despite the relatively dehydrated surface liquid.

Relatively little is known about the in vivo regulation of $\mathrm{Na}^{+}$ absorption across mammalian airways. Aldosterone, a potent mineralocorticoid that plays an important role in regulating the balance of $\mathrm{Na}^{+}$and $\mathrm{K}^{+}$transport across many epithelia, is one candidate for modulating $\mathrm{Na}^{+}$absorption across respiratory epithelia. Aldosterone has been shown to increase the rate of $\mathrm{Na}^{+}$ absorption in the kidney (8), the gastrointestinal tract (9), and the sweat duct (10). The change in the rate of aldosteronedependent $\mathrm{Na}^{+}$transport in the colon is associated with a parallel change in the transepithelial PD (11). It has been suggested that excessive sensitivity to aldosterone may contribute to the gastrointestinal dysfunction in CF (12).

In the present study, we investigated the contribution of aldosterone to the raised nasal PD in CF. First, the relationship between absolute aldosterone excretion and nasal PD was compared in CF and normal subjects. Second, the sensitivity of $C F$ nasal epithelial PD to the effects of aldosterone was investigated by administering spironolactone, an aldosterone antagonist, to a small group of $\mathrm{CF}$ and normal subjects. Because spironolactone has been shown to reduce PD in tissues known to be aldosterone sensitive (13), e.g. the colon, the effect of this antagonist on rectal $\mathrm{PD}$ in $\mathrm{CF}$ and normal subjects was measured for comparison.

\section{METHODS}

Basal aldosterone excretion rates and nasal $P D$. Five normal subjects (three females and two males, $24.4 \pm 1.4 \mathrm{yr}$, weight 56.8 $\pm 0.6 \mathrm{~kg}$ ) and five adult CF patients (three females and two males, $27.8 \pm 4.7 \mathrm{yr}$, weight $55.6 \pm 0.8 \mathrm{~kg}$ ) had measurements of aldosterone excretion and nasal PD between June and September in an air-conditioned CRU. The diagnosis of CF was established by clinical criteria and elevated concentrations of chloride in sweat $(>80 \mathrm{mEq} /$ liter). None of the CF patients had evidence of cor pulmonale, hepatic insufficiency, or significant oxygen desaturation $\left(\mathrm{O}_{2}\right.$ saturation $\left.>88 \%\right)$. Each of the subjects had normal baseline renal function. Two of the CF patients were taking antibiotics and three were taking pancreatic enzyme supplements. Twenty-four-hour urinary aldosterone excretion was measured by radioimunoassay (Bioscience, Van Nuys, CA) while each subject was on a daily $\mathrm{Na}^{+}$intake of $150 \mathrm{mEq}$. Each of the CF patients had by dietary history an ad libitum intake of $>150$ $\mathrm{mEq}$ of $\mathrm{Na}^{+}$per day during the 2 wk before the study. Nasal PDs were measured at the conclusion of the 24-h urine collection.

Effect of spironolactone on aldosterone excretion and epithelial $P D s$. Four adult CF patients and five normal subjects were studied (December and September-October, respectively) to assess the effect of spironolactone on aldosterone metabolism and transepithelial PD (CF patients = three females and one male, $22.5 \pm 2.0 \mathrm{yr}, 54.8 \pm 1.2 \mathrm{~kg}$; normal subjects $=$ three females and two males, $26.2 \pm 1.5 \mathrm{yr}, 55.2 \pm 0.7 \mathrm{~kg}$ ). Two of the CF patients and two of the normal subjects were in the group studied in the summer (above). None of the patients had evidence of cardiac or hepatic dysfunction and each had normal baseline renal function and urinalysis. During the study, three patients were taking antibiotics and three were taking pancreatic enzymes. Each subject was admitted to the CRU for 3 days for a physical examination, baseline studies, and initiation of spironolactone. Baseline measurements included serum electrolytes, BUN, and creatinine; 24-h urinary excretion of $\mathrm{Na}^{+}, \mathrm{K}^{+}$, creatinine (North Carolina Memorial Hospital laboratory) and aldosterone (Bioscience, radioimmunoassay); and nasal and rectal PDs (see below). Dietary histories for the $2 \mathrm{wk}$ prior to admission to the CRU disclosed that each subject had a routine daily intake of $>150$ $\mathrm{mEq}$ of $\mathrm{Na}^{+}$. During the study, each subject continued an ad libitum daily intake of $>150 \mathrm{mEq}$ of $\mathrm{Na}^{+}(210.0 \pm 31.9 \mathrm{mEq} /$ day). After a baseline was established, spironolactone (gift of Searle, Chicago, IL) was administered orally at $200 \mathrm{mg} /$ day in divided doses. After $48 \mathrm{~h}$ of observation and measurements of serum electrolytes, BUN, and creatinine, the subjects were discharged for 7-10 days of spironolactone therapy. Study subjects were instructed to avoid potassium supplements and excessive intakes of food with high potassium content. Serum electrolytes and BUN were measured every $48-72 \mathrm{~h}$ during the period of drug administration. Then subjects were readmitted to the CRU, blood was drawn $3 \mathrm{~h}$ after the last dose of spironolactone and assayed by gas chromatography (Searle) for canrenone, the active metabolite of spironolactone, to assess drug absorption, and the remaining spironolactone tablets were counted to assess compliance. Clinical chemistry and PD measurements were then repeated. ${ }^{1}$

All procedures were approved by the Committee on the Rights of Human Subjects at the University of North Carolina and informed consent was obtained.

Measurement of nasal and rectal epithelial PDs. PDs were measured between a Ringer-perfused exploring bridge and a reference bridge in the subcutaneous space of the forearm. Nasal PDs were measured under the inferior turbinate as previously described (4). A Ringer-perfused $(0.4 \mathrm{ml} / \mathrm{min})$ polyethylene- 50 catheter was used as an exploring bridge to record rectal PD through a sigmoidoscope at sites 5 and $10 \mathrm{~cm}$ caudal to the anal sphincter.

Data analysis. Measurements of nasal PD were expressed as the mean and maximal PD, as previously described (4). The rectal PD was calculated by the method of Rask-Madsen et al. (14) as the mean of the highest stable $(>5 \mathrm{~s})$ value recorded at each site. Changes induced during drug administration were assessed by paired $t$ analysis. All values shown represent the mean \pm SEM unless otherwise indicated.

\section{RESULTS}

Basal aldosterone excretion (summer measurements) of the five CF patients $(12.2 \pm 0.9 \mu \mathrm{g} / 24 \mathrm{~h})$ was similar to that of the

${ }^{1}$ Spironolactone was discontinued after $60 \mathrm{~h}$ in one asymptomatic $\mathrm{CF}$ subject because the BUN had increased from 9 to $28 \mathrm{mg} / \mathrm{dl}$, despite an ad libitum $\mathrm{Na}^{+}$ intake of $270 \mathrm{mEq} /$ day. The BUN returned to baseline after spironolactone was discontinued and parenteral saline was administered. Measurements of aldosterone excretion and nasal and rectal PDs are included for that subject after $60 \mathrm{~h}$ of drug. 
five control subjects $(13.6 \pm 1.5 \mu \mathrm{g} / 24 \mathrm{~h})$ and within the normal range. Despite similar aldosterone excretion, the mean nasal $P D$ of the CF patients $(-53.6 \pm 6.4 \mathrm{mV})$ was more than 2 -fold greater than the PD of the normal subjects $(-21.3 \pm 1.4 \mathrm{mV})$. The magnitude of this difference is similar to that described for a larger group of CF and normal subjects (4).

The effects of spironolactone on aldosterone excretion and nasal and rectal PD in CF and normal subjects are summarized in Table 1. During the control period, the urinary aldosterone excretion was normal for each subject and not different from the values measured during the summer. The baseline nasal PD of CF patients was again 2-fold greater than the voltage of normal subjects. Values for nasal PDs in both the CF and control groups were unchanged by spironolactone administration $(7.0 \pm 2.1$ and $6.7 \pm 0.3$ days, respectively). Although the number of subjects we studied is small, the magnitude and variance of the rectal PD values are similar to those of other $\mathrm{CF}$ and normal subjects with normal aldosterone excretion (14). After spironolactone the voltage across the rectal epithelium of CF and normal subjects was reduced. Urinary aldosterone excretion increased 4-fold in CF patients and nearly 3 -fold in normal subjects. The mean serum $\mathrm{K}^{+}$and BUN tended to increase in CF $(4.0$ to $4.5 \mathrm{mEq} / \mathrm{liter}$ and 10.8 to $18.3 \mathrm{mg} / \mathrm{dl}$ ) and normal subjects ( 4.2 to $4.5 \mathrm{mEq} / \mathrm{liter}$ and 14.8 to $17.4 \mathrm{mg} / \mathrm{dl}$ ). Spirometry was unchanged in $\mathrm{CF}$ subjects; this parameter was not measured in normal subjects.

Pill counts showed each CF and normal subject removed the appropriate number of tablets from the prescription bottle during the period of self-administration of the drug. Canrenone was detected in the plasma of each study subject. The plasma concentration of canrenone $3 \mathrm{~h}$ after spironolactone administration was $363.4 \pm 23.5 \mathrm{ng} / \mathrm{ml}$ in normal subjects and $254.0 \pm 28.5$ $\mathrm{ng} / \mathrm{ml}$ in CF patients.

\section{DISCUSSION}

Our data do not support the notion that aldosterone contributes to the raised PD noted across nasal epithelia in CF. We found no relationship between baseline aldosterone excretion and nasal PD when CF patients were compared with normal subjects. Aldosterone excretion rates of the CF patients were within the normal range of our reference laboratory and were not different from values obtained under similar conditions in age-matched healthy control subjects.

Several factors suggest our study accurately assessed aldosterone metabolism. First, 24-h aldosterone excretion rates yield good estimates of average circulating aldosterone concentrations (8). Second, all subjects studied in the summer were on standard diets with fixed $\mathrm{Na}^{+}$and $\mathrm{K}^{+}$intakes, thus minimizing the effect of differences in salt and volume status in our two subject groups. Third, all urine collections were performed in a CRU and 24-h creatinine measurements suggested complete collections.

The normal values for aldosterone excretion rates are also congruent with previous experience in CF patients who do not have far-advanced disease (14-16). Although some CF patients are presumed to have hyperaldosteronism secondary to cardiopulmonary, renal, or hepatic disease and the loss of salt via the kidney or sweat ducts (17-19), our patients demonstrate several characteristics which are associated with the maintenance of normal aldosterone metabolism: 1) "mild" clinical disease with no evidence of cardiac or hepatic insufficiency, 2) high ad libitum $\mathrm{Na}^{+}$intake, and 3) normal renal function. Consequently, it appears unlikely that excessive aldosterone secretion has a role in the interplay of processes in proximal airways that leads to "dehydrated" airway surface liquid in CF.

We also found no evidence to support the hypothesis that nasal epithelia in CF are excessively sensitive to normal circulating levels of aldosterone. Specifically, administration of the competitive aldosterone antagonist, spironolactone, induced no change in the magnitude of the nasal PD in CF (or normal) subjects. The strength of this evidence rests on the efficacy of spironolactone to antagonize the action of aldosterone. Several considerations suggest that spironolactone was effective in this regard. First, the nominal daily dose $(200 \mathrm{mg})$ is "maximal" for $55-\mathrm{kg}$ subjects. Second, gastrointestinal absorption, as reflected by the plasma concentration of the spironolactone metabolite canrenone, was normal in the CF subjects. Third, the frequency and duration $(\sim 7$ days) of drug administration would be expected to induce maximal effects. Finally, two physiologic effects of spironolactone were evident in both $\mathrm{CF}$ and normal subjects: a 2- to 4-fold increase in aldosterone excretion and a fall in rectal PD.

In summary, our data suggest that neither increased aldosterone secretion nor organ sensitivity to the hormone is likely to induce the raised PD in CF nasal epithelia that may be linked to increased or inappropriately maintained salt and water absorption. This finding is congruent with other recent observations. Nasal PDs of several patients with raised circulating levels of aldosterone and increased rates of aldosterone excretion (primary and secondary hyperaldosteronism) were not raised $(4,20)$. In addition, exposure of airway epithelia excised from salt-loaded rabbits to a supramaximal concentration of aldosterone did not affect bioelectric properties or ion transport (21). Whereas the findings of others in the rat may indicate some species variability (22), our results suggest that most airway epithelia, including human, are not a target for aldosterone.

Since aldosterone does not appear to regulate the rate of $\mathrm{Na}^{+}$ absorption across CF or normal nasal epithelia, the mechanism by which $\mathrm{Na}^{+}$flow is regulated remains unresolved. If, indeed, inappropriate salt and water transport across CF airway surfaces is responsible for dehydration of surface liquid, the elucidation of the normal regulation of active ion transport and passive ion permeabilities may hold the key to a therapeutic approach on a manifestation of the disease that favors the development of ultimately fatal respiratory infections.

\section{REFERENCES}

1. Wood RE, Boat TF and Doershuk CF 1976 State of the art: cystic fibrosis. Am Rev Respir Dis 113:833-878

Table 1. The effect of spironolactone on aldosterone excretion and nasal and rectal PD in CF and normal subjects (mean \pm SEM)

\begin{tabular}{|c|c|c|c|c|c|c|}
\hline & \multicolumn{3}{|c|}{$\mathrm{CF}$} & \multicolumn{3}{|c|}{ Normal } \\
\hline & $n$ & Control period & $\begin{array}{c}\text { During } \\
\text { spironolactone }\end{array}$ & $n$ & Control period & $\begin{array}{c}\text { During } \\
\text { spironolactone }\end{array}$ \\
\hline Aldosterone $(\mu \mathrm{g} / 24 \mathrm{~h})^{*}$ & 4 & $15.5 \pm 1.7$ & $59.5 \pm 5.6 \dagger \ddagger$ & 5 & $13.8 \pm 1.4$ & $33.7 \pm 6.2 \dagger$ \\
\hline Nasal PD (mV) & 4 & & & 5 & & \\
\hline Mean & & $-52.1 \pm 4.3 \ddagger$ & $-53.6 \pm 1.4 \ddagger$ & & $-21.2 \pm 3.1$ & $-21.6 \pm 3.2$ \\
\hline Maximal & & $-70.1 \pm 5.1 \ddagger$ & $-73.3 \pm 1.7 \ddagger$ & & $-30.6 \pm 3.8$ & $-30.3 \pm 3.3$ \\
\hline Rectal PD (mV) & 3 & $-51.9 \pm 12.3$ & $-26.6 \pm 10.9 \dagger$ & 3 & $-46.3 \pm 9.5$ & $-31.7 \pm 7.4$ \\
\hline
\end{tabular}

* Normal $=2-25 \mu \mathrm{g} / 24 \mathrm{~h}$.

$\dagger$ Different from control period $(p<0.05)$

$\ddagger$ Different from normal $(p<0.05)$. 
2. David PB, Di Sant'Agnese PA 1980 A review. Cystic fibrosis at forty-quo vadis? Pediatr Res 14:83-87

3. Dearborn DG 1976 Water and electrolytes of exocrine secretions. In: Mangos JA and Talamo RC (eds) Cystic Fibrosis: Projections into the Future. Symposia Specialists, New York, pp 179-191

4. Knowles M, Gatzy J, Boucher R 1981 Increased bioelectric potential difference across respiratory epithelia in cystic fibrosis. N Engl J Med 305:1489-1495

5. Boucher RC, Stutts MJ, Knowles MR, Cantley L, Gatzy JT $1985 \mathrm{Na}^{+}$transport in cystic fibrosis nasal epithelia: abnormal basal rate and response to adenylate cyclase activation. Clin Res 33:467A

6. Knowles MR, Stutts MJ, Spock A, Fischer N, Gatzy JT, Boucher RC 1983 Abnormal ion permeation through cystic fibrosis respiratory epithelium. Science 221:1067-1070

7. Knowles M, Gatzy J Boucher R. 1983 Relative ion permeability of normal and cystic fibrosis nasal epithelium. J Clin Invest 71:1410-1417

8. Laragh JH, Sealey JE 1973 The renin-angiotensin-aldosterone hormonal system and regulation of sodium, potassium, and blood pressure homeostasis. In: Orloff J, Berliner RW (eds) Handbook of Physiology. Section 8: Renal Physiology. American Physiological Society, Washington, DC, pp 831-908

9. Fordtran JS, Ingelfinger FJ 1968 Absorption of water, electrolytes, , and sugars from the human gut. In: Code CF (ed) Handbook of Physiology, Section 6 Alimentary Canal, Vol III, Intestinal Absorption. American Physiologica Society, Washington, DC, pp 1457-1490

10. Forman Barr H, Mulrow PJ 1976 Effect of corticosteroids on water and electrolyte metabolism. In: Greep RO, and Astwood EB (eds) Handbook of Physiology, Section 7-Endocrinology, Vol VI. American Physiological Society, Washington, DC, pp 179-189

1. Frizzell RA, Schultz SG 1978 Effect of aldosterone on ion transport by rabbit colon in vitro. J Membrane Biol 39:1-26

12. Hopfer U, Will PC, Dearborn DG 1980 Cystic fibrosis: a secondary endocrine or target tissue sensitivity problem in epithelial electrolyte transport? In:
Perspectives in Cystic Fibrosis, Proceedings of the 8th International Congress on Cystic Fibrosis. Toronto, Canadian Cystic Fibrosis Foundation, p 20A

13. Edmonds CJ 1970 Measurement of rectal electrical potential difference as an instant screening-test for hyperaldosteronism. Lancet 2:624-627

14. Rask-Madsen J, Schiotz PO, Bartels U, Nielsen MD, Becher-Christensen F 1975 Electrical polarization of rectal mucosa and excretion of tetrahydroaldosterone in patients with cystic fibrosis of pancreas and in normal subjects. Acta Paediatr Scand 64:81-86

15. Montalvo JM, McCaa CS, Cole WQ 1967 Aldosterone metabolism in children with cystic fibrosis and their parents. J Endocrinol Metab 28:582-585

16. Orenstein DM, Henke KG, Costill DL, Doershuk CF, Lemon PJ, Stern RC 1983 Exercise and heat stress in cystic fibrosis patients. Pediatr Res 17:267269

17. Haschke F, Gotz M, Parth K, Popow C, Schilling R 1981 Plasma aldosterone elevation due to renal sodium wasting in a boy with cystic fibrosis. Acta Paediatr Scand 70:763-764

18. Rapaport R, Levine LS, Petrovic M, Wilson T, Draznin M, Bejar RL, Johanson A, New MI 1981 The renin-aldosterone system in cystic fibrosis. J Pediatr $98.768-771$

19. Simopoulos AP, Lapey A, Boat TF, di Sant'Agnese PA, Bartter FC 1971 The renin-angiotensin-aldosterone system in patients with cystic fibrosis of the pancreas. Pediatr Res 5:626

20. Knowles MR, Gatzy JT, Boucher RC 1982 Spironolactone effects on epithelial potential difference and aldosterone excretion in cystic fibrosis. In: Cystic Fibrosis Club Abstracts, Twenty-Third Annual Meeting. Washington, DC, Cystic Fibrosis Foundation, p 43

21. Boucher RC, Gatzy JT 1983 Characteristics of sodium transport by excised rabbit trachea. J Appl Physiol 55:1877-1883

22. Legris GJ, Will PC, Hopfer U 1982 Inhibition of amiloride-sensitive sodium conductance by indoleamines. Proc Natl Acad Sci USA 79:2046-2050

\title{
Whole Body Protein Synthesis and Energy Expenditure in Very Low Birth Weight Infants
}

\author{
C. CATZEFLIS, Y. SCHUTZ, J.-L. MICHELI, C. WELSCH, M. J. ARNAUD, AND E. JÉQUIER
}

Institute of Physiology, Faculty of Medicine, University of Lausanne, Lausanne [C.C., Y.S., E.J.]; Service of Paediatrics, University Hospital, CHUV, Lausanne [J.-L.M.]; and Nestlé Products Technical Assistance Co. Ltd., Research Department, La Tour-de-Peilz [C.W., M.J.A.J, Switzerland

\begin{abstract}
The aim of the present work was to study whole body protein synthesis and breakdown, as well as energy metabolism, in very low birth weight premature infants $(<1500 \mathrm{~g})$ during their rapid growth phase. Ten very low birth weight infants were studied during their first and second months of life. They received a mean energy intake of $114 \mathrm{kcal} / \mathrm{kg}$. day and $3 \mathrm{~g}$ protein $/ \mathrm{kg}$. day as breast milk or milk formula. The average weight gain was $15 \mathrm{~g} /$ $\mathrm{kg}$ - day. The apparent energy digestibility was $88 \%$, i.e. 99 $\mathrm{kcal} / \mathrm{kg} \cdot$ day. Their resting postprandial energy expenditure was $58 \mathrm{kcal} / \mathrm{kg}$-day, indicating that $41 \mathrm{kcal} / \mathrm{kg}$.day was retained. The apparent protein digestibility was $89 \%$, i.e. $2.65 \mathrm{~g} / \mathrm{kg}$ - day. Their rate of protein oxidation was 0.88 $\mathrm{g} / \mathrm{kg}$-day so that protein retention was $1.76 \mathrm{~g} / \mathrm{kg} \cdot$ day. There was a linear relationship between $\mathbf{N}$ retention and $\mathrm{N}$ intake $(r=0.78, p<0.001)$. The slope of the regression line indicates a net efficiency of $N$ utilization of $67 \%$. Estimates of body composition from the energy balance,
\end{abstract}

Received July 20, 1984; accepted February 27, 1985.

Correspondence to Prof. E. Jéquier, Institute of Physiology, Universiy of Lausanne, Rue du Bugnon 7, CH-1011 Lausanne, Switzerland. coupled with $\mathbf{N}$ balance method, showed that $25 \%$ of the gain was fat and $75 \%$ was lean tissue. Whole body protein synthesis and breakdown were determined using repeated oral administration of ${ }^{15} \mathrm{~N}$ glycine for $60-72 \mathrm{~h}$, and ${ }^{15} \mathrm{~N}$ enrichment in urinary urea was measured. Protein synthesis averaged $11.2 \mathrm{~g} / \mathrm{kg}$. day and protein breakdown $9.4 \mathrm{~g} /$ $\mathrm{kg} \cdot$ day. Muscular protein breakdown, as estimated by 3methylhistidine excretion, contributed to $12 \%$ of the total protein breakdown. There was a positive correlation $(r=$ $0.68, p<0.05$ ) between protein synthesis and protein gain, as well as between resting energy expenditure and protein gain $(r=0.58, p<0.01)$. The slope of the regression line indicated that $1 \mathrm{~g}$ of protein gain required the synthesis of five times more protein $(5 \mathrm{~g})$ and resulted in an extra energy expenditure of $10 \mathrm{kcal}$. Thus, the net cost of protein synthesis in these very low birth weight infants was 2 kcal/ g. (Pediatr Res 19: 679-687, 1985)

Abbreviations

3-MHis, 3-methylhistidine 